\title{
Chronic effects of a monogenean Ligictaluridus floridanus (Ancyrocephalidae) infection on channel catfish (Ictalurus punctatus) growth performance
}

\author{
Jaime Luis Rábago-Castro, Jesús Genaro Sánchez-Martínez, Roberto Pérez-Castañeda, \\ María de la Luz Vázquez-Sauceda, Gonzálo Ruiz-Orozco
}

\begin{abstract}
Autonomous University of Tamaulipas, Faculty of Veterinary Medicine and Zootechnics, Laboratory of Parasitology, Tamaulipas, Mexico
\end{abstract}

Received April 11, 2013

Accepted January 23, 2014

\begin{abstract}
In aquaculture, acute infections may result in fish mortality, but in many cases the chronic effects of infections are not readily detected, and may result in a decrease in fish growth. Ligictaluridus floridanus is a gill monogenean parasite prevalent on channel catfish (Ictalurus punctatus) farms in Northeastern Mexico. In order to assess and evaluate the impact of the chronic infection with this monogenean, 400 six-month-old catfish fingerlings from a hatchery, with a fork length of $10-15 \mathrm{~cm}$ were used in this study. Catfish naturally infected with L. floridanus (parasite abundance was 18) were divided in two groups of 200 fish. One group was treated with formalin, and infection was eliminated during a week, while the other group was not treated, and was used as a control. In total, 111 fish of each group were selected, placed into aquaria, and observed for 12 weeks. Indicators of growth such as fork length, mean weight, condition index, specific growth rate, feed conversion index and feed consumed were assessed. Significant differences $(P<0.05)$ between the treated group and control were found in the mean weight (127.85 $\mathrm{g}$ and $107.63 \mathrm{~g})$ and specific growth rate (1.79 and 1.58), respectively. No significant differences were found in the other growth indicators assessed. We proved that growth performance of channel catfish is affected by infection with L. floridanus, which influence the farm economy. This is the first report on the effect of L. floridanus on the growth performance of channel catfish.
\end{abstract}

Trematode, gill ectoparasites, cage culture, fish, weight

Channel catfish (Ictalurus punctatus) is widely cultured throughout Mexico and is the most cultured fish species in Tamaulipas State in the northeast of the country. This species is chronically infected with the monogenean Ligictaluridus floridanus, with a high intensity and prevalence in the floating cage systems used in fish production (RábagoCastro et al. 2011). The continuous transmission of monogeneans occurs in crowded environments, such as cage culture, causing subclinical pathological damage. Despite this, there are no studies focusing on the chronic impact of $L$. floridanus infections on channel catfish growth, where one of the most important economic factors is the feed, which can reach $50 \%$ or more of the production costs for this fish (Hanson et al. 2007). Regardless of the importance of tropical aquaculture, there are few concerted efforts to determine the diseases that affect this fish (Lio-Po and Lim 2002). Ligictaluridus (Cleidodiscus) has been considered as a threat to fingerling catfish (Meyer 1991) but no studies have been done on the specific effect of infection with this parasite on growth performance.

The aim of this study was to assess the effect of a chronic infection by Ligictaluridus floridanus on the growth performance of channel catfish.

\section{Materials and Methods}

Experimental procedures were in compliance with the Code of Professional Ethics of Veterinary Medicine and Zootechnics in Mexico, and revised and approved by the Ethics Committee. A total of 400 six-month-old channel catfish (10-15 cm of fork length) were purchased at the hatchery Acuacultivos Santo Tomás, Abasolo,

Address for correspondence:

Jaime Luis Rábago-Castro

Laboratory of Parasitology

Faculty of Veterinary Medicine and Zootechnics

Autonomous University of Tamaulipas

Dr. Norberto Treviño Zapata, Carretera Victoria - Mante Km. 5

Cd. Victoria, Tamaulipas, México. C.P. 87000

Phone: +52 (834) 3125078

E-mail: jrabago@uat.edu.mx

http://actavet.vfu.cz/ 
Tamaulipas, Mexico. At the farm, samples of 7 fish were examined. All fish were infected with Ligictaluridus floridanus (Monogenean) and Henneguya exilis (Myxosporea). Parasite abundance of L. floridanus was 18, which was calculated as the total number of parasites per host, including uninfected specimens (Audenaert et al. 2003). Fish were divided into two groups of 200 fish and placed in two 1921 tanks. After a week, fish from one tank (treated group) were treated $\times 3$ at 2-day intervals, using immersion baths with formaldehyde $(250 \mathrm{pm})$ to eliminate the monogenean infection. After the treatment, 10 fish were euthanized with benzocaine (120 mg/l, Cedrosa, México) and sampled. The eight gill arches of fish were dissected and their tissue was checked for infection with the monogenean using a compound microscope (all fish were negative for infection with the monogenean). The second group was not treated (untreated group). A total of 111 fish were selected from the treated group, and placed into three 371 aquaria with 37 fish per aquarium; the same was done with the untreated group. The experiment ran for 12 weeks, and each aquarium was supplied with constant freshwater flow and aeration. Fish were fed $\times 2$ per day, 6 days per week to satiation without wastage with a commercial feed (Nutripec ${ }^{\mathrm{TM}}$, Mexico).

At the beginning of the experiment, fish were immersed and anaesthetized (benzocaine $40 \mathrm{mg} / \mathrm{l}$, Cedrosa, Mexico), weighed with a scale (Ohaus-Pionner ${ }^{\mathrm{TM}}$, China) and measured (fork length in $\mathrm{cm}$ ). Two fish from the untreated group $(n=6)$ were euthanized with benzocaine $(120 \mathrm{mg} / \mathrm{l})$ previously dissolved in water to determine the parasite abundance; the same was done to the treated group to maintain the same level of fish density with respect to the infected group and to examine the fish and confirm the absence of infection. Further samplings of 2 fish per aquarium (6 per group) were carried out every 2 weeks until the 12 weeks of the experiment were completed. Fish mortality was recorded daily.

The growth performance indicators of body weight (Bw, g), mean weight (Mw, g), fork length (FL, cm), condition index (K), specific growth rate (SGR, \%/day), feed conversion index (FCI), weekly feed consumption (\% of body weight) and feed consumed ( $\mathrm{g}$ and \%/biomass) were evaluated according to Sánchez et al. (1996). Water properties such as temperature $\left({ }^{\circ} \mathrm{C}\right)$ and dissolved oxygen $(\mathrm{mg} / \mathrm{l})$ were recorded daily with an oxymeter (YSI ${ }^{\circledR}$, Mod. 85, USA), while $\mathrm{pH}$, un-ionized ammonia $(\mathrm{mg} / \mathrm{l})$, alkalinity $\left(\mathrm{mg} / \mathrm{l}\right.$ as $\left.\mathrm{CaCO}_{3}\right)$ and hardness $(\mathrm{mg} / \mathrm{l}$ as $\mathrm{CaCO}_{3}$ ) were recorded weekly with a kit (LaMotte ${ }^{\circledR}, \mathrm{AQ}-12$, USA).

Water quality indicators were compared with Student's $t$-test; growth performance indicators were calculated for each aquarium (treated and untreated) at 2-week intervals and compared using one-way ANOVA. Differences were considered significant at $P \leq 0.05$.

\section{Results}

Water quality indicators stayed within the normal range for channel catfish fingerling culture, and were not significantly different between the groups. Fish growth measured as fork length $(\mathrm{cm})$ was not significantly different $(P>0.05)$ between the two groups, although it was observed that the length of fish from the treated group was larger compared to the untreated group (Table 1). Significant differences $(P<0.05)$ in the mean weight of fish were observed, where treated fish were heavier than untreated fish at weeks 4 and 12 (Table 1). Specific growth rate $(\% /$ day $)$ was significantly different $(P<0.05)$ throughout the trial, with the treated group showing higher values compared to the untreated group (Table 2). The feed consumed, feed conversion index and condition index did not show significant

Table 1. Fork length and mean weight of channel catfish infected with Ligictaluridus floridanus (treated and untreated group) measured at 2-week intervals.

\begin{tabular}{|c|c|c|c|c|c|c|}
\hline \multirow{2}{*}{ Week } & \multicolumn{2}{|c|}{ Fork length $(\mathrm{cm})$} & \multirow{2}{*}{$P$} & \multicolumn{2}{|c|}{ Mean weight (g) } & \multirow{2}{*}{$P$} \\
\hline & Treated & Untreated & & Treated & Untreated & \\
\hline 0 & $12.97 \pm 0.06$ & $12.79 \pm 0.12$ & 0.084 & $28.23 \pm 0.31$ & $28.41 \pm 0.55$ & 0.645 \\
\hline 2 & $14.34 \pm 0.38$ & $13.86 \pm 0.29$ & 0.161 & $35.67 \pm 0.67$ & $35.24 \pm 1.34$ & 0.649 \\
\hline 4 & $15.20 \pm 0.15$ & $15.06 \pm 0.04$ & 0.197 & $44.26 \pm 0.74$ & $42.53 \pm 0.47$ & $0.027 *$ \\
\hline 6 & $16.41 \pm 0.24$ & $16.08 \pm 0.43$ & 0.314 & $56.70 \pm 5.11$ & $51.83 \pm 8.80$ & 0.454 \\
\hline 8 & $17.67 \pm 0.71$ & $17.02 \pm 0.22$ & 0.206 & $70.42 \pm 6.98$ & $64.35 \pm 6.25$ & 0.325 \\
\hline 10 & $19.99 \pm 0.45$ & $18.88 \pm 0.58$ & 0.060 & $103.12 \pm 9.34$ & $91.24 \pm 10.5$ & 0.218 \\
\hline 12 & $21.59 \pm 0.84$ & $20.11 \pm 0.51$ & 0.059 & $127.85 \pm 5.14$ & $107.63 \pm 10.5$ & $0.040 *$ \\
\hline
\end{tabular}

Data are expressed as mean $\pm \mathrm{SD}$ of 6 fish measured per group each 2 weeks. $* P<0.05$ 
Table 2. Specific growth rate (\%/day) of channel catfish (Ictalurus punctatus) infected with Ligictaluridus floridanus (treated and untreated group) measured at 2-week intervals.

\begin{tabular}{cccc}
\hline Week & Treated & Untreated & $P$ \\
\hline $0-2$ & $1.67 \pm 0.21$ & $1.53 \pm 0.35$ & 0.603 \\
$2-4$ & $1.54 \pm 0.25$ & $1.34 \pm 0.19$ & 0.350 \\
$4-6$ & $1.74 \pm 0.57$ & $1.34 \pm 1.25$ & 0.637 \\
$6-8$ & $1.80 \pm 0.18$ & $1.85 \pm 0.74$ & 0.902 \\
$8-10$ & $2.38 \pm 0.07$ & $2.17 \pm 0.12$ & 0.061 \\
$10-12$ & $1.55 \pm 0.39$ & $1.18 \pm 0.26$ & 0.260 \\
$1-12$ & $1.79 \pm 0.04$ & $1.58 \pm 0.10$ & $0.030^{*}$ \\
\hline
\end{tabular}

Data expressed as \%/day ( \pm SD) of 6 fish measured per group each 2 weeks. $* P<0.05$

differences between the groups. A total of 9 mortalities were observed in the untreated group and 6 mortalities in the treated group. At week 10, the highest parasite abundance during the experiment was observed in the untreated group (Fig. 1).

\section{Discussion}

Monogenean infections are common worldwide in cultured sea and freshwater species of fish (You et al. 2008; Merella et al. 2009). In this study, results showed that chronic exposure to L. floridanus reduced the mean weight of channel catfish. The negative effects on the mean weight may be due to the irritation of the monogenean haptor on gills. Monogeneans feed mainly on the superficial layers of skin and gills, which irritates the host (Noga 1996; Yardimci and Pekmezci 2012). Irritation is common in fish ectoparasite infections, and Ligictaluridus (Cleidodiscus) cause stress in fish (Meyer 1991). Although stress was not measured, it is possible that discomfort due to parasites may cause severe negative effects in fish physiology (Barandica and Tort 2008), including an increase of the metabolic rate. Moreover, feeding and parasite activity may take an energetic toll on the fish. However, periods when no significant differences in the mean weight were found were probably due to fish compensatory growth (Wright et al. 2007).

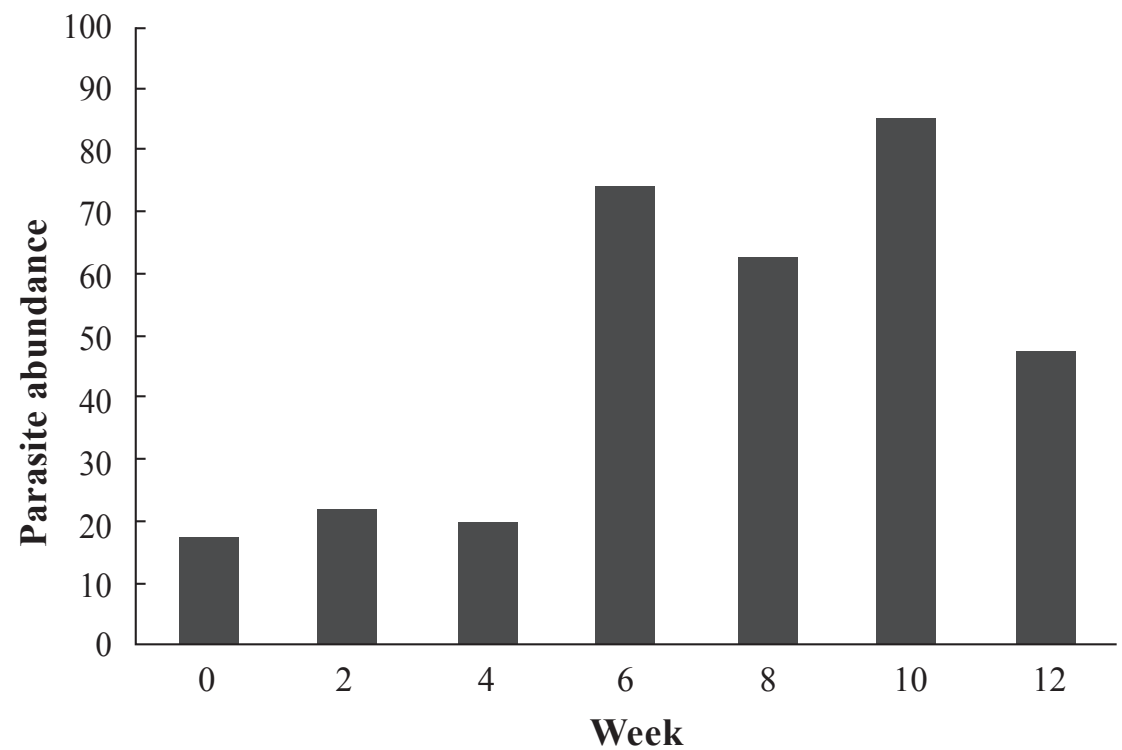

Fig.1. Parasite abundance (mean of parasites in all fish sampled) of Ligictaluridus floridanus in channel catfish. The number of fish examined is 6 per week. 
A lower specific growth rate in infected fish with respect to the treated group was detected during the growth trial. It seems that access to food is an important factor to maintain the growth of fish infected with parasites. Parasites impose an energetic charge on the host, however, the growth rate of fish infected with helminthes is not affected when they have access to unrestricted food (Barber et al. 2008).

In our study, fish were feed ad libitum $\times 2$ a day. High density of aquaria may reduce or hinder the availability of food to smaller fish due to competition. Abundance of $L$. floridanus showed 3 periods (weeks 4, 8 and 12) with a decrease in the number of parasites per host, possibly as a consequence of host resistance; similar immunological responses have been observed in cage-cultured tilapia infected with the gill monogenan Neobenedenia melleni (Robinson et al. 2008).

Dead fish in the treated and infected untreated groups during the trial may be due to normal mortality observed in commercial culture. One of the factors associated with fish mortality in cultured systems is related to stress. Environmental and management farm practices including social stress may affect the immune system of fish, leading to or predisposition to disease (Reček et al. 2009).

Mean weight and specific growth rates are important indicators for evaluation of fish performance, and they are related to the farm economy. Considering the period in which this species reaches the marketable size, this may involve a decrease in profits.

Monogenea can normally be asymptomatically present on gills of healthy fish (Martins 1998; Repulles-Albelda et al. 2013). This group is among the helminthes most commonly found on fish farms in Mexico, with a great potential of impacting fish culture (FloresCrespo and Flores-Crespo 2003). There is evidence that the effect of gill monogeneans on fish cause a reduction on host growth (Forwood et al. 2012). Similarly, in salmon culture it has been estimated that the greatest financial losses due to the ectoparasite sea lice are caused by reduced growth and poor feed conversion ratio (Johnson et al. 2004). It is possible that exposure of channel catfish to L. floridanus impacts negatively their growth performance and in consequence the farm's profits. It is recommended that channel catfish farms should take into account the impact of this parasite, especially in young fish, and treat them accordingly.

\section{Acknowledgments}

We thank Programa para el Mejoramiento del Profesorado (PROMEP) of Secretaría de Educación Pública, México (grant /103.5/11/3635) for financing this study and for the scholarship to Gonzalo Ruiz Orozco. We also thank Comité de Sanidad Acuícola de Tamaulipas, A.C. for its support in fish transportation. The authors thank FOMIX-Cotacyt Tamaulipas for covering the publication costs of this article.

\section{References}

Audenaert V, Huyse T, Goemans G, Belpaire C, Volckaert FAMJ 2003: Spatio-temporal dynamics of the parasitic nematode Anguillicola crassus in Flanders, Belgium. Dis Aquat Organ 56: 223-233

Barandica LM, Tort L 2008: Neuroendocrinology and immunology of the fish response to stress (in Spanish). Rev Acad Colomb Cienc 37: 267-284

Barber I, Wright HA, Arnott SA, Wooton RJ 2008: Growth and energetics in the stickleback Schistocephalus host-parasite system: a review of experimental infection studies. Behaviour 145: 647-668

Flores-Crespo J, Flores-Crespo R 2003: Monogenean parasites in Mexican fish: a recapitulation. Tec Pecu Mex 41:175-192

Forwood JM, Harris J, Deveney MR 2012: Host impact of monogenean Lepidotrema bidyana infection and intensity estimates for onsite monitoring. Dis Aquat Org 100: 51-57

Hanson T, Anderson JD, Ibendahl G, Steeby J, Avery J 2007: Partial budgeting as a decision-making tool for catfish producers. Mississippi State University, Extension Service. Mississipi State University. USA. Publication 2437, 12 p.

Johnson SC, Treasurer JW, Bravo S, Nagasawa K, Kabata Z 2004: A review of the impact of parasitic copepods on marine aquaculture. Zool Stud 43: 229-243

Lio-Po GD, Lim LHS 2002: Infectious diseases of warm water fish in fresh water. In: Woo PTK, Bruno DW, Lim LHS (Ed): Diseases and disorders of finfish in cage culture. CABI Publishing, CAB International, Wallingford, Oxon, UK, pp. 231-281 
Martins ML 1998: Evaluation of the addition of ascorbic acid to the ration of cultivated Piaractus mesopotamicus (Characidae) on the infrapopulation of Anacanthorus penilabiatus (Monogenea). Braz J Med Biol Res 31: 655-658

Merella P, Cherchi S, Garippa G, Fioravant ML, Gustinelli A, Salati F 2009: Outbreak of Sciaenacotyle panceri (Monogenea) on cage-reared meagre Argyrosomus regius (Osteichthyes) from the western Mediterranean Sea. Dis Aquatic Org 86: 169-173

Meyer FP 1991: Aquaculture disease and health management. J Anim Sci 69: 4201-4208

Noga EJ 1996: Fish disease. Mosby, St. Louis, MO, USA, 366 p.

Rábago-Castro JL, Sánchez-Martínez JG, Loredo-Osti J, Gómez-Flores R, Tamez-Guerra P, Ramírez-Pfeiffer C 2011: Temporal and spatial variations of ectoparasites on cage-reared Channel catfish, Ictalurus punctatus, in Tamaulipas, México. J World Aquacult Soc 42: 406-411

Reček L, Palíková M, Lojek A, Navrátil S 2009: Health status of the nase (Chondrostoma nasus) in breeding farms from the Jihlava river basin. ActaVet Brno 78: 99-106

Repulles-Albelda A, Kostadinova A, Raga JA, Montero FE 2013: Seasonal population dynamics of Zeuxapta seriolae (Monogenea: Heteraxinidae) parasitising Seriola dumerili (Carangidae) in the Western Mediterranean. Vet Parasitol 193: 163-171

Robinson RD, O'Connor NPG, Steele D 2008: Interactions between cage-cultured hybrid Tilapia and a marine monogenean, Neobenedenia melleni, in Jamaica. N Am J Aquacult 70: 68-73

Sánchez JG, Speare DJ, MacNair N, Johnson G 1996: Effects of a prophylactic chloramines-T treatment on growth performance and condition indices of rainbow. J Aquat Anim Health 8: 278-284

Wright HA, Wootton RJ, Barber I 2007: Compensatory growth in threespine sticklebacks (Gasterosteus aculeatus) inhibited by experimental Schistocephalus infections. Can J Fish Aquat Sci 64: 819-826

Yardimci B, Pekmezci GZ 2012: Gill histopathology in cultured sea bass (Dicentrarchus labrax (L.) co-infected by Diplectanum aequans (Wagener, 1857) and Lernanthropus kroyeri (van Beneden, 1851). Ankara Üniv Vet Fak Derg 59: 61-64

You P, Wang Y, Sun X, Qiang X, Cone D 2008: Seasonality of Gyrodactylus brachymystacis ergens on farmed rainbow trout, Onchorhyncus mykiss (Walbaum), in central China, with a report of an infection on wild manchurian trout, Brachymystak lenok (Pallas). J Fish Dis 31: 941-945 